\title{
PENERAPAN MODEL PEMBELAJARAN AKTIF INDEX CARD MATCH UNTUK MENINGKATKAN HASIL BELAJAR SISWA KELAS VIIIA DI MTS BURHANUL ABRAR SITUBONDO
}

\author{
Candra Yulianto, *Dassucik \\ Pendidikan Ekonomi, STKIP PGRI Situbondo, Indonesia \\ *email korespondensi: dassucik75@gmail.com
}

\begin{abstract}
Active learning is learning that invites students to learn actively. When students learn actively, Index Card Match is an instructional technique from active learning in the reviewing strategies section that can help students remember what they have learned and test the skills and knowledge they have received. This research was conducted on VIII grade students of MTs Burhanul Abrar starting in November / December 2013 with 35 students as the research site. This type of research is classroom action research using a qualitative approach, data collection using observation, tests, interviews and documentation. The data collected was in the form of students' answers to the preliminary tests, I and II conducted by the researcher. Through Active Learning Index Card Match, where the formulation of the problem is how to apply the Active Learning Model Index Card Match to improve student learning outcomes in Economics with Basic Competencies "Describing the Relationship Between Resource Scarcity and Unlimited Human Needs" Class VIIIA at MTs Burhanul Abrar School year 2013/2014? and the research objective is to want to know how to apply the Active Learning Model Index Card Match to improve student learning outcomes in Economics with the Basic Competence "Describing the Relationship Between Resource Scarcity and Unlimited Human Needs" Class VIIIA at MTs Burhanul Abrar 2013/2014 Academic Year ". The research respondents of MTs Burhanul Abrar class VIII were selected purposively. The data collected were in the form of daily tests I and II and interviews were conducted during the research. on the results of classical student completeness on daily tests. In daily tests, it increased from cycle I to cycle II. Where in the first cycle, the percentage of completeness was $77 \%$ classically from 27 students, students who did not complete it was $23 \%$ classically or 8 students and cycle II was $100 \%$ of 35 students classically who followed 35 students' daily tests. Thus the increase in the percentage of completeness of learning outcomes from cycle I to cycle II is $23 \%$, from the results of the study it is concluded that the application of Active Learning Index Card Match can increase the percentage of student learning outcomes completeness at MTs Burhanul Abrar class VIIIA in the 2013/2014 academic year.
\end{abstract}

Keyword : Aktif Index Card Match, Learning Outcomes

\begin{abstract}
Abstrak : Pembelajaran aktif adalah Suatu pembelajaran yang mengajak peserta didik untuk belajar secara aktif. Ketika peserta didik belajar dengan aktif, Index Card Match merupakan salah satu teknik instruksional dari belajar aktif bagian reviewing strategies (strategi pengulangan) yang dapat membantu siswa mengingat apa yang telah mereka pelajari dan menguji kemampuan serta pengetahuan yang telah mereka terima. Penelitian ini dilaksankan pada siswa MTs Burhanul Abrar kelas VIII mulai bulan Nopember/Desember 2013 dengan siswa 35 yang menjadi tempat penelitian. Jenis penelitian ini adalah penelitian tindakan kelas dengan mengunakan pendekatan kualitatif, pengumpulan data mengunakan observasi, test, wawancara dan dokumentasi. Data yang di kumpulkan berupa jawaban siswa terhadap test pendahuluan, I dan II yang dilakukan
\end{abstract}


oleh peneliti. Melalui pembelajaran Aktif Index Card Match, dimana rumusan masalah adalah bagaimana Penerapan Model Pembelajaran Aktif Index Card Match Untuk meningkatkan hasil belajar siswa pada mata pelajaran Ekonomi dengan Kompetensi Dasar "Mendeskripsikan Hubungan Antara Kelangkaan Sumber Daya Dengan Kebutuhan Menusia Tidak Terbatas" Kelas VIIIA Di MTs Burhanul Abrar Tahun Pelajaran 2013/2014? dan tujuan penelitian adalah Ingin mengetahui bagaimana Penerapan Model Pembelajaran Aktif Index Card Match Untuk meningkatkan hasil belajar siswa pada mata pelajaran Ekonomi dengan Kompetensi Dasar "Mendeskripsikan Hubungan Antara Kelangkaan Sumber Daya Dengan Kebutuhan Menusia Tidak Terbatas" Kelas VIIIA Di MTs Burhanul Abrar Tahun Pelajaran 2013/2014". Responden penelitian siswa MTs Burhanul Abrar kelas VIII dipilih secara purposive sanpling area. Data yang dikumpulkan berupa Ulangan Harian I dan II dan wawancara dilakukan selama penelitian berlangsung. pada hasil ketuntasan siswa secara klasikal pada ulangan harian. Pada ulangan harian mengalami peningkatan dari siklus I sampai siklus II. Dimana siklus I, persentase ketuntasan yaitu 77\% secara klasikal dari 27 siswa, siswa yang tidak tuntas 23\% secara klasikal atau 8 Siswa dan siklus II yaitu $\mathbf{1 0 0 \%}$ dari 35 siswa secara Klasikal yang mengikuti ulangan harian 35 siswa. Dengan demikian peningkatan persentase ketuntasan hasil belajar dari siklus I ke siklus II adalah $\mathbf{2 3 \%}$, dari hasil penelitian disimpulkan bahwa penerapan pembelajaran Aktif Index Card Match dapat meningkatkan persentase ketuntasan hasil belajar siswa pada MTs Burhanul Abrar kelas VIIIA tahun pelajaran 2013/2014.

Kata Kunci : Aktif, Index Card Match, Hasil Belajar

\section{PENDAHULUAN}

Sumber daya manusia merupakan salah satu faktor penting dalam keberhasilan pembangunan di segala bidang. Hingga kini pendidikan masih diyakini sebagai wadah dalam pembentukan sumber daya manusia yang diinginkan. Melihat begitu pentingnya pendidikan dalam pembentukan sumber daya manusia, maka peningkatan mutu pendidikan merupakan hal yang wajib dilakukan secara berkesinambungan guna menjawab perubahan zaman.

Masalah peningkatan mutu pendidikan tentulah sangat berhubungan dengan masalah proses pembelajaran. Proses pembelajaran yang sementara ini dilakukan di lembaga-lembaga pendidikan kita masih banyak yang mengandalkan cara-cara lama dalam penyampaian materinya. Mengajar tidak hanya mentransfer ilmu pengetahuan kepada peserta didik, tetapi juga merupakan kegiatan guru membimbing/memfasilitasi siswa menemukan pengetahuan dan pengalaman belajar tersebut. Dalam konteks pembaharuan pendidikan ada 3 (tiga) isu utama yang perlu disoroti, yaitu pembaharuan kurikulum, peningkatan kualitas pendidikan, dan efektifitas metode pembelajaran. Peningkatan layanan pendidikan, khususnya didalam kelas erat kaitannya dengan usaha guru dalam merancang pengajaran melalui strategi pembelajaran. strategi pembelajaran adalah tehnik atau cara dalam melakukan suatu proses pembelajaran. 
Selama melakukan Observasi awal penelitian juga berusaha mengumpulkan data-data mengenai hasil belajar peserta didik. Berdasarkan data yang diperoleh dari guru mata pelajaran IPS menunjukkan hasil belajar yang diraih peserta didik masih rendah, yaitu dapat dilihat pada nilai ulangan harian dan tugas yang diberikan oleh guru bidang study dan nilai rata-rata 55. Sebab itu peneliti punyak inisiatif untuk melakukan penelitian menggunakan pembelajaran Index Card Match untuk menignkatkan hasil belajar siswa Kelas VIIIA Di MTs Burhanul Abrar.

Hal tersebut menjadi pendorang peneliti untuk mengadakan Classroom Action Research atau penelitian tindakan kelas. Berdasarkan uraian tersebut, maka diambil sebuah inisiatif untuk melaksanakan penelitian tindakan kelas dengan judul " Penerapan Model Pembelajaran Aktif Index Card Match Untuk meningkatkan hasil belajar siswa pada mata pelajaran IPS dengan Kompetensi Dasar "Mendeskripsikan Hubungan Antara Kelangkaan Sumber Daya Dengan Kebutuhan Menusia Tidak Terbatas” Kelas VIIIA Di MTs Burhanul Abrar Tahun Pelajaran 2013/2014.

\section{METODE PENELITIAN}

Rancangan penelitian yang dipandang sesuai dengan tujuan penelitian adalah rancangan Penelitian Tindakan Kelas (PTK) yang dilaksankan sebayak dua siklus. Jenis penelitian tindakan ini termasuk penelitian tindakan kelas. Penelitian ini dikatakan penelitian tindakan kelas dari awal sampai berakhirnya penelitian. Rancangan pembelajaran yang digunakan berdasarkan dari Metode penelitian Model Kurt Lewin, yaitu penelitian tindakan kelas yang digambarkan dalam bentuk spiral yang terdiri dari empat fase yaitu fase perencanaan (planning); tindakan (action); pengamatan (observation); dan refleksi (reflection). Penelitian ini berorentasi pada pengkajian masalah - masalah praktis yang dihadapi guru dalam kelas, dan hasilnya dapat diaplikasikan oleh guru sendiri dalam rangka memperbaiki pemanfaatan belajar mengajar yang di hadapi. Wijaya Kusuma dan Dedi Dwitagama (2010:21)

Langkah-lagkah dan prosedur penelitian ini mengikuti Metode yang dikembangkan oleh model Kurt Lewin berupa suatu siklus spiral yang meliputi kegiatan perencanaan (planing); pemberian tindakan action; pengamatan (observation); dan refleksi (reflection) yang membentuk siklus demi siklus sampai tuntas penelitian, sehingga dapat diperoleh data yang dapat disimpulkan sebagai jawaban dari permasalahan peneliti.

Subyek penelitian ini adalah siswa kelas VIIIA semester I Mata Pelajaran Ekonomi Tahun Pelajaran 2013/2014. subyek penelitian ini komposisinya putra sebabkan antara siswa putra putri dipisahkan dan jumlah siswa 25 siswa. 
Pengumpulan data dilakukan dengan maksud untuk memperoleh bahan-bahan yang relevan dan akurat, dimana Metode yang digunakan memiliki ciri - ciri yang berbeda. Menurut Arikunto (dalam Wahyuningsih, 2006:22), Metode pengumpulan data adalah cara yang digunakan peneliti untuk mengumpulkan data. Adapun Metode yang digunakan dalam penelitian ini adalah Metode Observasi, wawancara, Metode test dan Dokumentasi.

Data penelitian terkumpul dianalisis dengan menggunakan analisis Deskriptif Kualitatif. Data penelitian terkumpul terdiri dari test, hasil wawancara, hasil observasi, dan dokumentasi.

Langkah analisis hasil observasi diawali dengan menghitung jumlah skor hasil observasi pada masing-masing siswa, kemudian menggolongkan ke dalam kategorisasi yang telah ditentukan, untuk menghitung jumlah skor digunakan pedoman sebagai berikuT. Persentasi Ketuntasan belajar siswa dalam proses pembelajaran dicari : dengan rumus :

$$
P=\frac{n}{N} X 100
$$

Keterangan : $\quad P=$ Persentase Ketuntasan Hasil Belajar siswa

$$
\begin{aligned}
& \mathrm{n}=\text { Jumlah siswa yang tuntas belajar } \\
& \mathrm{N}=\text { Jumlah seluruh siswa }
\end{aligned}
$$

Kriteria Ketuntasan Belajar dinyatakan sebagai berikut (a). daya serap individual, seorang siswa dinyatakan tuntas belajar apabila telah mencapai sekor $>70$ dari skor maksimal 100. (b). Daya serap klasikal jika satu kelas dikatakan tuntas apabila terdapat skor minimal mencapai $85 \%$ siswa yang telah mencapai skor dari atau sama dengan $>70$ dari skor maksimal.

\section{HASIL DAN PEMBAHASAN}

\section{Hasil}

Berdasarkan hasil pengamatan sebelum tindakan siswa yang tuntas 57\% dari siswa 20 secara klasikal dan siswa yang tidak tuntas 43\% dari siswa 15 sehingga tidak memenuhi kriteria ketuntasan yaitu 85\% secara klasikal. Pada saat ulangan harian pada pertemuan Siklus I diperoleh data dalam dua kali pertemuan dan satu pertemuan ulangan harian 8 siswa yang tidak tuntas dan 27 siswa tuntas yang mengikuti ulangan harian karena siswa 8 tersebut memperoleh nilai $<70$ dari skor 100 dan 27 siswa tuntas secara klasikal yang mencapai nilai $>70$. siswa yang tuntas mencapai $77 \%$ dan siswa yang tidak tuntas $23 \%$. Hasil belajar siswa pada siklus I sangat meningkat dibandingkan dengan sebelum dilakukan pelajaran Aktif Index Card Match. Pada Siklus II diperoleh data dalam dua kali pertemuan dan satu ulangan harian dari 35 siswa semua tuntas secara klasikal yang mencapai nilai $\geq 70$. Siswa yang tuntas 
mencapai $100 \%$. Hasil belajar siswa pada siklus II sangat meningkat dibandingkan dengan sebelum dilakukan pelajaran Aktif Index Card Match.

Analisa perbandingan Sebelum Tindakan, Siklus I dan II Hasil Ulangan Harian

Tabel.1 Perbandingan Sebelum Tindakan, Siklus I dan Siklus II

T. NILAI

SEBELUM TINDAKAN

SIKLUS I

SIKLUS II

Jml Siswa Presentasi Jml Siswa Presentasi Jml Siswa PRESENTA

SI

T. TUNTAS

20

$57 \%$

27

$77 \%$

35

$100 \%$

T. TUNTAS

$43 \%$

8

$23 \%$

0

$0 \%$

JUMLAH

35

$100 \%$

35

$100 \%$

35

$100 \%$

Sumber Data : Siswa MTs Burhanul Abrar

Tabel diatas menunjukkan bahwa adanya peningkatan terhadap hasil belajar siswa dari silkus I ke siklus II dalam peningkatan tersebut sudah sesuai dengan ketuntasan secara klasikal. Pada table 1 bisa digambarkan dengan grafik sebagai berikut.

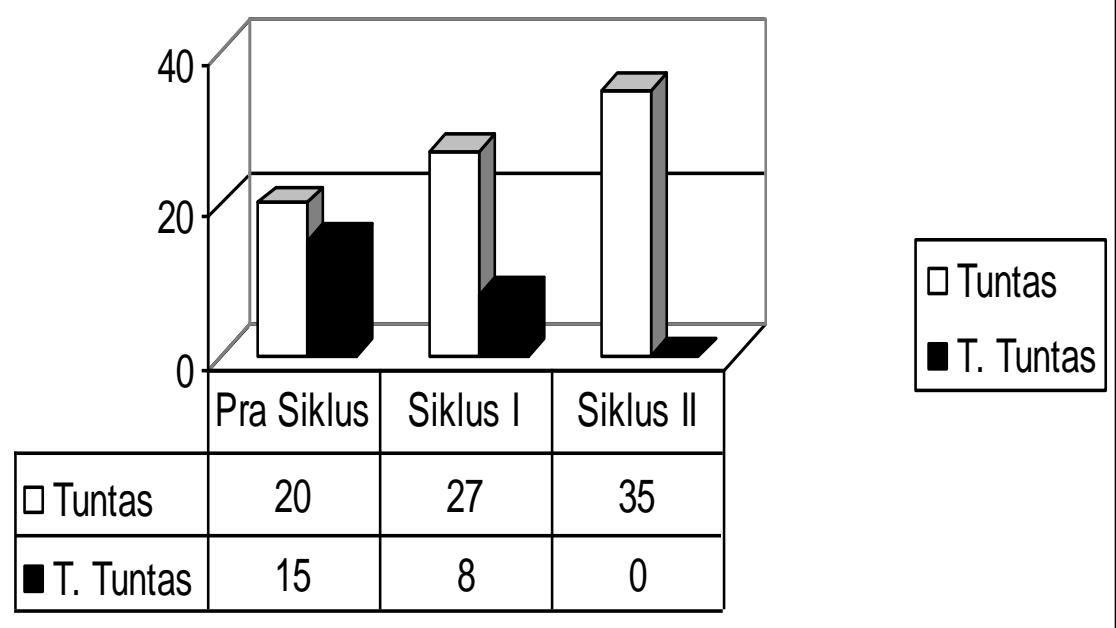

Gambar 1 Perbandingan Setiap Siklus

\section{Pembahasan}

Pembelajaran Aktif Index Card Match ini bertujuan untuk mengukur persentase ketuntasan hasil belajar siswa dari Ulangan harian yang pada penelitian ini mengalami keberhasilan dalam penerapan yang ditandai dengan persentase ketuntasan yang meningkat dari sebelum penerapan pembelajaran Aktif Index Card Match dan setelah penerapan dengan 2 siklus, pada siklus I dan II hasil belajar siswa meningkat sebesar 23\%.

Dalam peningkatan hasil belajar siswa dapat disebabkan oleh penggunaan metode pembelajaran. Metode pembelajaran yang digunakan sebelum pembelajaran Aktif Index Card Match adalah ceramah pada saat pembelajaran Aktif Index Card Match dilakukan yaitu salah satu model pembelajaran yang dapat mendorong siswa untuk ikut aktif dalam belajar. model 
ini merupakan cara belajar-mengajar yang lebih menekankan pada pemahaman materi yang diajarkan guru dengan menyelesaikan soal-soal. Dalam aplikasinya model pembelajaran Aktif Index Card Match tidak hanya menginginkan siswa untuk belajar ketrampilan dan isi akademik. Kondisi seperti ini akan memberikan kontribusi yang cukup berarti untuk membantu siswa yang kesulitan dalam mempelajari konsep-konsep belajar, pada akhirnya setiap siswa dalam kelas dapat mencapai hasil belajar yang maksimal.. Hal ini dibuktikan dari persentase ketercapaian hasil belajar siswa secara klasikal pada siklus I, 77\% dan siklus II, $100 \%$.

Berdasarkan peningkatan hasil belajar siswa yang dicapai siswa melalui pembelajaran Aktif Index Card Match maka siswa sangat menyukai pembelajaran Aktif Index Card Match. Hal ini dikatakan pada saat wawancara bahwa penerapan pembelajaran Aktif Index Card Match ini siswa menjadi lebih aktif dan siswa dapat melakukan atau menyelsaikan dengan mudah ulangan harian, sehingga perkembangan siswa dalam proses belajar mengajar dapat terkontrol dengan baik oleh guru. Menurut guru dengan pembelajaran Aktif Index Card Match ini melatih siswa berkomunikasi dengan sesama anggota kelompok, selain itu siswa juga dapat berfikir kritis dan cepat dalam memahami materi pelajaran, akibatnya dapat terselesaikan dengan baik sesuai dengan waktu yang telah dijadwalkan oleh guru pada satuan pembelajaran maupun rencana pembelajaran.

Secara keseluruhan hasil penelitian ini, menunjukkan bahwa pembelajaran Aktif Index Card Match dapat dijadikan alternatif dalam meningkatkan ketuntasan siswa dalam pembelajaran dan meningkatkan hasil belajar siswa dalam pembelajaran Ekonomibaik secara klasikal dan individu.

\section{SIMPULAN}

Dari hasil penelitian dan pembahasan, pembelajaran Aktif Index Card Match. Pada Kompetensi dasar "Mendeskripsikan Hubungan Antara Kelangkaan Sumber Daya Dengan Kebutuhan Menusia Tidak Terbatas", pada siswa kelas VIIIA MTs Burhanul Abrar Situbondo dapat diambil kesimpulan sebagai berikut: 1) Berdasarkan hasil pengamatan sebelum tindakan siswa yang tuntas $57 \%$ dari siswa 20 secara klasikal dan siswa yang tidak tuntas $43 \%$ dari siswa 15 sehingga tidak memenuhi kriteria ketuntasan yaitu 85\% secara klasikal.

Pada saat ulangan harian pada pertemuan Siklus I diperoleh data dalam dua kali pertemuan dan satu pertemuan ulangan harian 8 siswa yang tidak tuntas dan 27 siswa tuntas yang mengikuti ulangan harian karena siswa 8 tersebut memperoleh nilai $<70$ dari skor 100 dan 27 siswa tuntas secara klasikal yang mencapai nilai $>70$. siswa yang tuntas mencapai $77 \%$ dan siswa yang tidak tuntas 23\%. Pada Siklus II diperoleh data dalam dua kali 
pertemuan dan satu ulangan harian dari 35 siswa semua tuntas secara klasikal yang mencapai nilai $\geq 70$. Siswa yang tuntas mencapai $100 \%$.

\section{DAFTAR RUJUKAN}

Hisyam Zaini, Bermawy Munthe and Sekar Ayu Aryani. 2008. Strategi Pembelajaran Aktif. Pustaka Insan Madani Yogyakarta.

Mel Silberman. 2009. Aktive Learning (101 Strategi Pembelajaran Aktif). Madani Yogyakarta Nursalam, 2007 Strategi Belajar Mengajar Ilmu Pengetahuan Sosial, Resum Materi. Situbondo

Mulyasa.H.E. 2011. Praktik Peneltian Tindakan Kelas. PT Remaja Rosdakarya Bandung Sudiyono. 2011. Metode Penelitian Kuantitatif kualitatif Dan R\&D. CV. Alfabeta Bandung Suharsimi Arikunto.2010. Dasar Evaluasi Pendidikan. PT Bumi Aksara Jakarta

Sanjaya, Wina. 2005. Pembelajaran dalam Implementasi Kurikulum Berbasis Kompetensi. Jakarta : Kencana.

Wijiya Kusumah, and Dedi Dwitagama. 2010. Mengenal Penelitian Tindakan Kelas.PT Indeks, Jakarta Barat.

Zainal Aqib, 2006 Penelitian Tindakan Kelas. CV Yrama Widja : Bandung Herdian. http://akmaldebayor.blogspot.com/2010/05/snowball-throwing_08.html.

Diakses tanggal 10 Agustus 2013

Muhammad Faiq Dzaki http://www.pengertiandefinisi.com/2012/01/pengertianpembelajarankooperatif.html diakses pada tanggal 10 agustus 2013 